\title{
HODGKIN LYMPHOMA AND ITS ASSOCIATION WITH EPSTEIN-BARR VIRUS IN KURDISTAN, NORTHERN IRAQ
}

\author{
RAWA YOUSIF HAMA SALIH, MBCHB* \\ RAFIL T.YAQO, MBCHB, FIBMS ** \\ SARAH AL ALLAWI, MBCHB*** \\ NASIR AL-ALLAWI, MBCHB, PHD, FRCPATH****
}

\section{Submitted 07 March 2019; accepted 06 July 2019}

\begin{abstract}
Background: Epstein Barr virus (EBV) has been linked to the etiology of several malignancies, including Hodgkin's Lymphoma (HL). However, the degree of this association varies between different geographical regions and age of EBV exposure. No study has addressed such an association in Kurdistan, northern Iraq, and thus this study was initiated.

Patients and methods: A total of 91 patients diagnosed as HL over a 10 year period were studied. These patients had their records and slides reviewed and the additional immunohistochemistry, including that for LMP1 as well as in situ hybridization for EBER performed.

Results: The patients had a mean age (SD) of 28.8 (16.2) years and had a male to female ratio of 1.7:1. They included 3.3\% with Nodular Lymphocyte Predominant HL (NLPHL) and 96.7\% Classical HL (cHL). The most common 2 subtypes of the latter were nodular sclerosis (NS) and mixed cellularity (MC) at $52.7 \%$ and $36.6 \%$ respectively. It was found that 40 cases (44.0\%) were latent membrane protein 1 (LMP1) and/or EBER positive. The positivity was significantly higher in males $(\mathrm{P}=0.009)$, mixed cellularity subtype $(\mathrm{P}<0.001)$ and in the ages $\geq 45$ and $\leq 15$ years when compared to those 16 - 44 years $(P=0.004)$.

Conclusion: HL in Iraqi Kurdistan demonstrates a frequency of EBV virus infection that approaches the levels seen in Western countries and is coupled with a changing histological pattern of classical HL from MC to NS. This is likely to be a reflection of the improving socioeconomic status of the population of the region.
\end{abstract}

Keywords: EBV, Hodgkin Lymphoma, Iraq, EBER, LMP1

Duhok Med J 2019; 13 (2): 74-83.

H odgkin lymphomas (HL) is a unique which the malignant cells (Reed-Sternberg (RS), Hodgkin (H) or Lymphocyte Predominant (LP) cells) constitute only a minority of the total tumor mass, with the bulk of the latter consisting of reactive non-neoplastic cells ${ }^{1}$. HL is classified according to the World Health organization into two distinct clinicopathological entities: classical Hodgkin lymphoma (cHL) and Nodular Lymphocyte Predominant Hodgkin Lymphoma (NLPHL). The former entity is further sub-classified into four subtypes: nodular sclerosis (NS), mixed cellularity (MC), lymphocyte rich (LR) and lymphocyte depletion (LD) ${ }^{2}$.

Several lines of evidence have linked Epstein-Barr virus (EBV) to the etiology of cHL, such as the biological tenability of EBV mediated B- cell transformation, the

\footnotetext{
* Department of Hematology, Azadi Teaching Hospital, Duhok, Kurdistan Region, Iraq

** Lecturer, Department of Pathology, College of Medicine, University of Duhok, Kurdistan Region, Iraq.

*** Azadi Teaching Hospital, Duhok, Kurdistan Region, Iraq..

**** Professor, Department of Pathology, College of Medicine, University of Duhok, Kurdistan Region, Iraq.

Correspondence author to: Nasir Al-Allawi, nallawi@yahoo.com, Mobil +9647504551494
} 
detection of clonal EBV genomes in the RS cells, and epidemiological links with infectious mononucleosis that represents a primary EBV infection ${ }^{3}$. Following primary infection with the EBV, which is a DNA herpes virus, the latently infected B lymphocytes are characterized by expression of six EBV nuclear antigens, three latent membrane proteins (LMP1, LMP2A and LMP2B) and two EBV encoded RNAs (EBER1 and EBER2) ${ }^{4}$. EBV has been detected in the malignant cells in variable proportion of HL, and this varies depending on the geographical origin, age, sex, and histological subtype ${ }^{3-}$ 5. While a variety of methods exist to detect EBV in the malignant cells, LMP1 and EBER assays in combination have been recommended as the most practical and effective methods ${ }^{6}$.

Malignant lymphoma according to the 2010 Iraqi Cancer Registry is the third most frequent malignancy in this country, with Hodgkin lymphoma accounting for $35 \%$ of the cases. In the Registry, the crude incidence of HL in 2010 was $1.58 / 100,000$ population ${ }^{7}$. Several studies have addressed the epidemiology and histological patterns of HL in Iraq over the past decades ${ }^{7-12}$. However, studies on its association with EBV infection are very limited in this population ${ }^{13}$. Accordingly, and in an attempt to determine the frequency and the associations of EBV infection among HL diagnosed and referred to a major pathology center in the Kurdistan region of Northern Iraq, the current study was initiated.

\section{MATERIALS AND METHODS}

This is a retrospective study on 91 cases diagnosed as HL in the period between
January 2008 and July 2018 at the department of pathology, central laboratory diagnostic center at Duhok, Iraqi Kurdistan. Records of included patients were retrieved from the pathology database including: age at the time of diagnosis, gender and clinical presenting features. All cases were reviewed and subclassified according to the World Health Organization (WHO) classification of hematologic malignancies, based on morphology and immunohistochemistry staining. The latter included at least the following: CD30, CD15, CD20, CD3, PAX5 and MUM12. For each case, additional three representatives sections were prepared. One was stained with Hematoxylin and Eosin (H\&E) to revise the histopathological diagnosis, another one was stained immunohistochemically for LMP-1, with the remaining section used for detection of EBER expression by in situ hybridization (ISH).

Statistical analysis, utilized Chi square test, and a $P$ value $<0.05$ was considered significant. Ethical approval for this study was obtained from Kurdistan board for medical specialties and Directorate of Health in Duhok, Kurdistan-Iraq.

\section{Immunohistochemical staining (include-} ing that for LMP-1):

Immunohistochemistry (IHC) was performed by polymer based detection method using the tissue microarray (TMA) constructed from representative cores taken from the appropriate formalin-fixed, paraffin-embedded tissue blocks after the original H\&E slides were reviewed. The microarray was assembled using a manual TMA kit (3D Histech, Bulgaria). The sections were de-waxed, rehydrated and 
the antigen retrieval was performed for 30 minute in citrate based buffer (pH6). A panel of primary monoclonal antibodies was applied CD20, CD30, CD15, CD3, PAX5, MUM1 and LMP1 [clone CS1-4] (Dako, Agilant, USA). Antigen localization was carried out using envision immunohistochemistry detection system (K8000, Dako, Agilant, USA). Antigen retrieval and immunostaining were done using an automated system developed by Dako-cytomatation (PT-link and Link 48, Dako, Agilant, USA). For the visualization of the antigen-antibody reaction: 3, 3 diaminobenzidine was used. Appropriate positive and negative controls were used.

\section{In situ hybridization staining for EBER:}

To detect EBER by in situ hybridization the EBV probe ISH kit (Zytovision, Germany) was used according to the manufacturer's instructions. The $4 \mu$ sections of tissue micro-array slides were deparaffinized, dehydrated, and predigested with the enzyme proteinase $\mathrm{K}$. Thereafter, the slides covered with the hybridization solution (containing fluorescein conjugated EBER nucleic acid probe), were incubated in a hybridizer (Agilent, USA). This was followed by the application of alkaline phosphatase conjugated antibody to fluorescein isothiocyanate, and finally the chromogen composed of BCIP/NBT (bromochloroindolylphosphate/ nitroblue tetrazolium chloride). Hematoxylin solution was applied as a counter-stain. The positive cases were defined as a nuclear dark blue staining. A negative control was run for each specimen.

\section{RESULTS}

The 91 enrolled patients had ages ranging from 5-75 years (mean $28.8 \pm 16.2$ ), and included 57 males and 34 females (M:F 1.7:1). The cohort included 17 children $(\leq$ 15 years) and 13 older adults ( $\geq 45$ years) constituting $\quad 18.7 \%$ and $14.3 \%$ respectively.

All of the patients had lymph node enlargement at presentation, with cervical lymphadenopathy being most frequent accounting for $59.3 \%$. cHL comprised $96.7 \%$ of cases and NLPHL $3.3 \%$ (Table $1)$. The most frequent subtype of $\mathrm{cHL}$ was $\mathrm{NS}$ at $52.7 \%$, followed by the MC at $36.3 \%$. No cases of lymphocytes depleted cHL were identified in the studied sample. Six cases were classed as cHL, based on the immunophenotype, but could not be sub-classified further because the material was either a tissue block or a bone marrow biopsy.

Table 1: Basic Characteristics and EBV Status in the 91 Iraqi Patients Enrolled.

\begin{tabular}{lc}
\hline Parameter & Number (\%) \\
\hline Age (years) & $17(18.7)$ \\
$\leq 15$ & $61(67.0)$ \\
$16-44$ & $14(14.3)$ \\
$\geq 45$ & $91(100)$ \\
Lymph node enlargement & \\
Gender & $58(62.6)$ \\
Male & $34(37.4)$ \\
Female & \\
Histology & $48(52.7)$ \\
Nodular Sclerosis & $33(36.3)$ \\
Mixed Cellularity & $1(1.1)$ \\
Lymphocyte rich & $0(0)$ \\
Lymphocyte depletion & $3(3.3)$ \\
Nodular Lymphocyte & \\
predominate & $6(6.6)$ \\
Classical/Not sub- & \\
classifiable & \\
EBV status (EBER/LMP1) & \\
Positive & $40(44.0)$ \\
\hline
\end{tabular}


The current study showed that the neoplastic cells were positive for latent membrane protein 1 (LMP1) in 35 cases (38.5\%) and for EBER in 36 (39.6\%) cases, while EBV positivity by LMP1 and/or EBER was seen in $40(44.0 \%)$ cases. Table 2 shows the distribution of LMP1/EBER positivity according to age and sex. It was noted that males with HL were much more likely to be EBV positive than females $(P=0.009)$. Furthermore, patients who were $\geq 45$ years had the highest rates of EBV positivity, followed by those $\leq 15$ years, while the least rates were noted in those in between, an observation which was significant $(P=0.004)$.

\begin{tabular}{lccc}
\hline \multicolumn{4}{c}{ Table 2: The Frequency of EBV Positive Cases of (HL) by Sex and Age; } \\
\hline \multicolumn{1}{c}{ Parameter } & $\begin{array}{c}\text { No. LMP1 positive } \\
(\boldsymbol{\%})\end{array}$ & $\begin{array}{c}\text { No. EBER positive } \\
(\boldsymbol{\%})\end{array}$ & $\begin{array}{c}\text { No. LMP1 and/or EBER positive } \\
(\boldsymbol{\%})\end{array}$ \\
\hline Gender & & & \\
Male (n 57) & $26(45.6)$ & $27(47.4)$ & $31(54.4)$ \\
Female (n 34) & $9(26.5)$ & $9(26.5)$ & $9(26.5)$ \\
P value & $\mathbf{0 . 0 7}$ & $\mathbf{0 . 0 4 9}$ & $\mathbf{0 . 0 0 9}$ \\
Age (years) & & & $8(47.1 \%)$ \\
$\leq 15$ (n 17) & $8(47.1)$ & $8(47.1)$ & $21(34.4 \%)$ \\
$16-44$ (n 61) & $18(29.5)$ & $20(32.8)$ & $11(84.6 \%)$ \\
$\geq 45$ (n 13) & $9(69.2)$ & $8(61.5)$ & $\mathbf{0 . 0 0 4}$ \\
P value & $\mathbf{0 . 0 2}$ & $\mathbf{0 . 1 2 3}$ & \\
\hline
\end{tabular}

Regarding EBV positivity in relevance to histological subtypes, it was noted that the highest frequencies were noted in the mixed cellularity subtype $(84.8 \%)$ which was significantly higher than in nodular sclerosis $(10.4 \%)[P<0.001]$ (Table 3 )

\begin{tabular}{lccc}
\hline \multicolumn{4}{c}{ Table 3: The Frequencies of EBV Positive Cases of HL by Histological Subtypes } \\
\hline \multicolumn{1}{c}{ Histological subtype } & $\begin{array}{c}\text { No. LMP1 } \\
\text { positive (\%) }\end{array}$ & $\begin{array}{c}\text { No. EBER } \\
\text { positive (\%) }\end{array}$ & $\begin{array}{c}\text { No. LMP1/EBER } \\
\text { positive (\%) }\end{array}$ \\
\hline Nodular Sclerosis (n 48) & $5(10.4)$ & $5(10.4)$ & $5(10.4)$ \\
Mixed cellularity (n 33) & $27(81.8)$ & $25(75.8)$ & $28(84.8)$ \\
Lymphocyte rich (1) & $0(0)$ & $1(100)$ & $1(100)$ \\
Nodular Lymphocyte predominant(3) & $0(0)$ & $0(0)$ & $0(0)$ \\
Classical/Not sub-classifiable (6) & $3(50)$ & $4(66.7)$ & $5(83.3)$ \\
\hline
\end{tabular}

\section{DISCUSSION}

The general characteristics of HL as observed in the current study as expected were similar to those reported in a smaller earlier series from Northern Iraq ${ }^{11}$. The age and sex distribution were also consistent with most earlier Iraqi studies $^{7,8,10,11,14}$. However, it appears that there is a change in the histological patterns, since earlier Iraqi studies, more 
than three decades ago, consistently reported $\mathrm{MC}$ as the most frequently encountered subtype ${ }^{8,9}$, while the current study and the more recent reports from Northern Iraq found that NS subtype to be the most common ${ }^{11,12,14}$. A similar trend was also noted in some neighboring Eastern Mediterranean countries, like Saudi Arabia and Jordan ${ }^{15,}{ }^{16}$, and the resultant distribution of HL subtypes resembles that reported in developed Western countries ${ }^{2,17,18}$.

EBV infection rates in HL vary worldwide, with high rates (61-85\%) reported from developing countries like India, South Africa, Kenya, Malaysia and Brazil $^{19-23}$, while rates from developed countries were lower ranging from $30-48 \%$ in UK, France and the USA. ${ }^{24-26}$ So our results of $44.0 \%$ are nearer to those reported in the developed countries, and to nearby countries like Jordan, UAE and Saudi Arabia ${ }^{16,27,28}$. This may be related to improvement of the living standards over the past two decades in our region and the latter neighboring countries, and it is well known that one of the important determinants of the EBV viral infection is socioeconomic status ${ }^{29}$.

The current study showed that EBV expression was related to the histologic subtype of HL, with the mixed cellularity (MC) subtype being the most likely to be associated with EBV infection, a finding which was highly significant when compared to the more common NS subtype. Such an observation has been well documented by many studies worldwide $^{2,3,13,16,23,27,30,31}$. The absence of EBV infection among the three patients with NLPHL in the current study is expected, as this subcategory is not usually associated with this virus, as demonstrated by previous studies ${ }^{16,31}$.

The highest frequency of EBV virus detection was encountered in older adults ( $\geq 45$ years) at $84.6 \%$, followed by children ( $\leq 15$ years) at $47.1 \%$, with the least rates seen among those in between at $34.4 \%$. Furthermore, this variation in EBV positivity in the three above age groups was significant. Such a pattern is similar to that encountered in developed countries ${ }^{32}$, while higher rates among children as expected in developing countries were reported from countries like Jordan, UAE, Egypt and Brazil ${ }^{16,27,31,33}$.

Another association is that with the male sex, this again has been consistently reported in several earlier studies ${ }^{5,16,32,33}$, and although the actual reason for such predilection has not been fully elucidated, it has been suggested that females tend to have a better immune response and thus are less likely to have their latent EBV infection transform ${ }^{34}$.

In conclusion it appears that the frequency of EBV virus infection in HL in Northern Iraq is approaching the levels seen in Western countries, and this is coupled with a changing histological pattern of classical HL to a pattern similar to the latter countries, which is likely to be a reflection of improving socioeconomic status of the population of the region and possibly reduced early childhood EBV exposure.

Conflict of Interest: None to declare.

\section{REFERENCES}

1. Kumar V, Abbas AK, Aster JC. Robbins Basic Pathology.10th edition. Philadelphia, Elsevier Publishers. 2017. 
2. Swerdlow SH, Campo E, Harris NL, Jaffe ES, Pileri SA, Stein $\mathrm{H}$, et al. WHO Classification of Tumors of Haemopietic and Lymphoid tissue. 4th edition.IARC 2017.

3. Massini G, Siemer D, Hohaus S. EBV in Hodgkin Lymphoma. Medit J Hemat Infect Dis. 2009; 1(2): e2009013.

4. Gandhi MK, Tellam JT, Khanna R. Epstein-Barr virus-associated Hodgkin's Lymphoma. Brit J Haematol. 2004; 125: 267-281.

5. Huang X, Nolte I, Gao Z, Vos H, Hepkema B, Poppema S, et al. Epidemiology of classical Hodgkin lymphoma and its association with Epstein barr virus in northern China. PLoS One. 2011; 6(6): e21152

6. Gulley ML, Glaser SL, Craig FE, Borowitz M, Mann RB, Shema SJ, Ambinder RF. Guidelines for interpreting EBER in situ hybridization and LMP1 immunohistochemical tests for detecting Epstein-Barr virus in Hodgkin Lymphoma. Amer J Clin Pathol. 2002; 117: 259-267.

7. Ministry of Health results on Iraqi Cancer Registry 2010. Iraqi Cancer Board, Baghdad-Iraq.

8. Yahya HI, Al-Saleem T, Tikriti F, Zardawi IM, Talib H. Hodgkin's disease in Iraq: A clinico-pathological study of 85 cases. Clin Oncol. 1979; 5:69-71

9. Alsabti EA. Histopathological subtypes of Hodgkin's disease in childhood in Iraq. Jpn J Exp Med. 1979; 49:319-24

10. Al-Barzinji RM. Hodgkin's Lymphoma: An epidemiological study in the Iraqi patients. The Iraqi Postgraduate Medical Journal. 2006; 5(3): 337-343.

11. Yaqo RT, Hughson MD, Sulayani FK, Al-Allawi NA. Malignant lymphoma in northern Iraq: A retrospective analysis of 270 cases according to the World Health Organization classification. Indian $\mathrm{J}$ Cancer. 2011; 48(4): 446-51.

12. Shamoon RP, Ali MD, ShabilaNP. Overview and outcome of Hodgkin's lymphoma:Experience of a single developing country oncology centre. PLoS One. 2018; 13(4): e0195629.

13. Al-Mudallal SS, Al-Sinjery GM. Immunohistochemical expression of Epstein Barr virus antigen latent membrane protein-1 and $\mathrm{Bcl}-2$ in classical Hodgkin lymphoma. Iraqi J Med Sci. 2012; 10(3): 234-242.

14. Fadhil MS, Al-Nueimy WM, Lazim AF.Hodgkin's lymphoma. An immunohistochemical profile in northern Iraq. Saudi Med J. 2014; 35(5):448-53

15. Al-Diab AI, Siddiqui N, Sogiawalla FF, Fawzy EM. The changing trends of adult Hodgkin's disease in Saudi Arabia. Saudi Med J. 2003; 24(6): 617-622.

16. Sughayer M, Haddad HA, Al-Yousef RM, El-khateeb M, Abu Rass H. Epstein-Barr virus and Hodgkin Lymphoma in Jordan. Hematol Oncol Stem Cell Ther. 2014; 7(2): 85-89.

17. Pourtsidis A, Doganis D, Baka M, Bouhoutsou

D, Varvoutsi

M, Synodinou M, et al. Successful Treatment in Children with Hodgkin Lymphoma in Greece; A 20-Year Experience in a Single Institution. 
Lymphoma. 2012; 2012, Article ID 215868, 7 pages.

18. Shenoy P, Maggioncalda A, Malik N, Flowers CR. Incidence Patterns and Outcomes for Hodgkin Lymphoma Patients in the United States. Advances in Hematology. 2011; 2011; Article ID 725219, 11 pages.

19. Karnik S, Srinivasan B, Nair S, Hodgkin's lymphoma: immunohistochemical features and its association with EBV LMP-1. Experience from a South Indian hospital. Pathology. 2003 ;35(3):20711

20. Engel M, Essop M F, Close P, Hartley P, Pallesen G, Sinclair-Smith C. Improved prognosis of Epstein-Barr virus associated childhood Hodgkin's lymphoma: study of 47 South African cases. J Clin Pathol. 2000; 53(3):1826.

21. Elgui de Oliveira D, Bacchi MM, Abreu ES. Hodgkin's disease in adult and juvenile groups from two different geographic regions in Brazil: characterization of clinicopathologic aspects and relationship with EB virus infection. Am J Clin Pathol. 2002;118: 25-30.

22. Weinreb M, Day PJ, Niggli F, Green EK, Nyong'o AO, Othieno-Abingo $\mathrm{NA}$, et al. The consistent association between EB virus and Hodgkin's disease in children in Kenya. Blood. 1996; 87:3828-3836.

23. Peh SC, Kim LH, Mun KS, Tan EL, Sam CK, Poppema S. Epstein-Barr virus (EBV) subtypes and variants in malignant tissue from Malaysian patients. J Clin Exp Hematopathol. 2003; 43(2): 61-9.
24. Andriko JA, Aguilera NS, Nandedkar MA. Childhood Hodgkins disease in the United States:an analysis of histologic subtypes and association with EB virus. Mod Pathol. 1997; 10:366-371.

25. Pallesan G, Hamilton-Dutoit SJ, Rowe M, Young LS. Expression of EB virus latent gene products in tumor cells of Hodgkin's disease. Lancet. 1991; 337:320-322.

26. Brousset P, Chittal S, Schleifer D, Icart J, Payen C, Huguet FR, et al. Detection of EB virus messenger RNA in Reed-Sternberg cells of Hodgkin's disease by in situ hybridization with biotinylated probes on specially processed modified acetone methyl benzoate xylene (ModAMex) sections. Blood. 1991; 77:1781-1786.

27. Al-Salam S, John A, Daoud S, Chong SM, Castella A. Expression of Epstein-Barr virus in Hodgkin lymphoma in a population of United Arab Emirates nationals. Leuk Lymphoma. 2008; 49 (9): 1769-77

28. Al-kuraya K, Narayanappa R, AlDayel F, El-Solh H, Ezzat A, Ismail $\mathrm{H}$, et al. Epstein-Barr virus infection is not the sole cause of high prevalence of Hodgkin's lymphoma in Saudi Arabia. Leuk Lymphoma. 2006; 47: 707-713.

29. Glaser SL, Lin RJ, Stewart SL, Ambinder RF, Jarrett RF, Brousset $P$, et al. Epstein-Barr virus-associated Hodgkin's disease: epidemiological characteristics in international data. Int. J. Cancer. 1997; 70: 375-382

30. Carbone A, Gloghini A. Epstein Barr Virus-associated Hodgkin Lymphoma. 
Cancers (Basel). 2018; 10(6). pii: E163.

31. Audouin J, Diebold J, Nathwani B, Ishak $\mathrm{E}$, MacLennan $\mathrm{K}$, MuellerHermelink HK, et al. Epstein-Barr virus and Hodgkin's Lymphoma in Cairo, Egypt J Hematopathol. 2010; 3: 11-18.

32. Chang ET, Zheng T, Lennette ET, Weir EG, Borowitz M, Mann RB, et al. Heterogeneity of risk factors and antibody profiles in Epstein-Barr virus genome positive and negative Hodgkin lymphoma. J Infect dis. 2004; 189: 2271-2281.
33. Campos AHJFM, Moreira A, Ribeiro KB, Paes RP, Zerbini MC, Aldred V, et al. Frequency of EBV associated classical Hodgkin Lymphoma decreases over a 54-year period in a Brazilian population. Scientific reports. 2018; 8: 1849.

34. Whitacre CC, Reingold SC, O'Looney PA. A gender gap in autoimmunity. Science. 1999; 283: 1277-1278. 


\section{ثوختة}

\section{هودجكين ليمفوما وطريَانا وي ل طةل فيروسي أبستين-بار ل هةريما كوردستانا العراق}

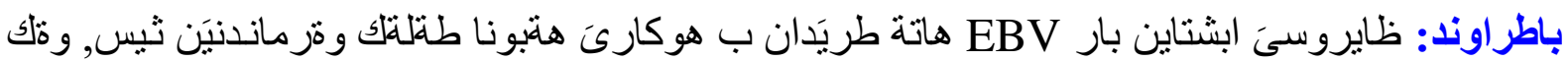

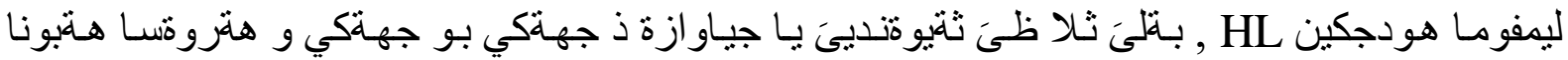

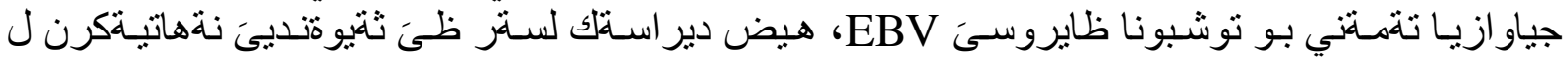

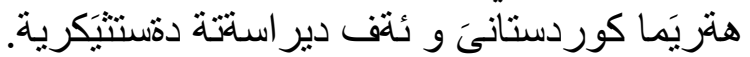

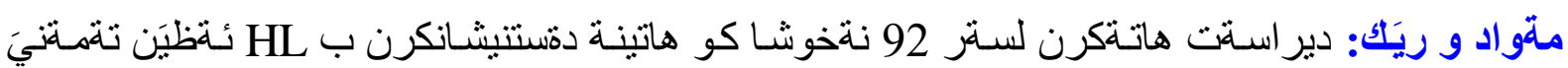

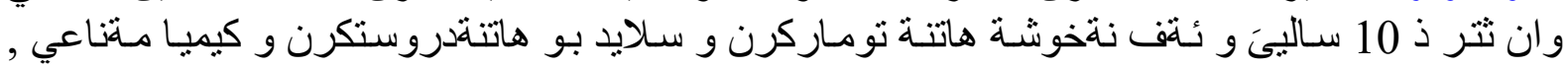

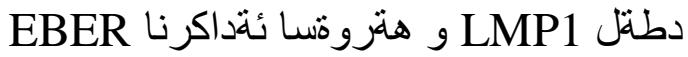

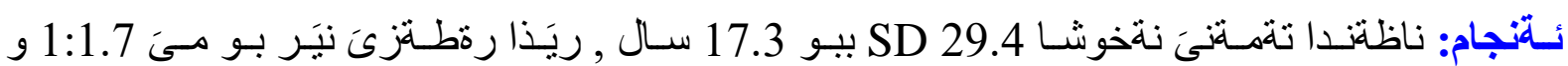

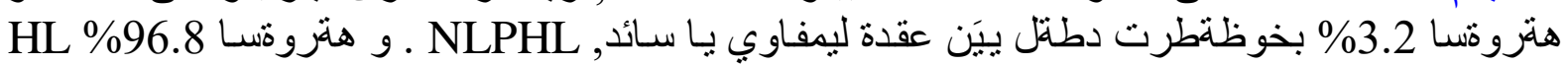

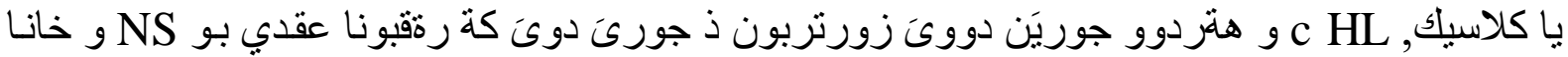

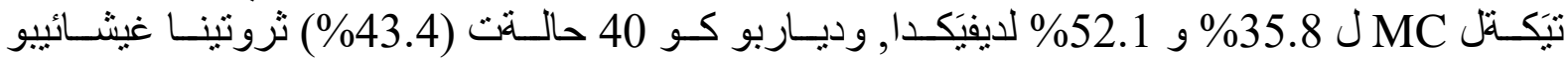

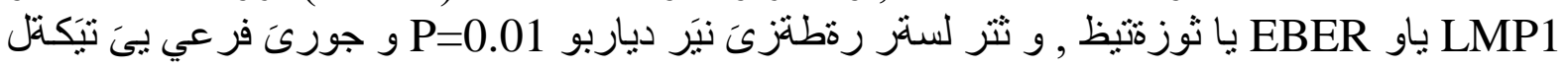

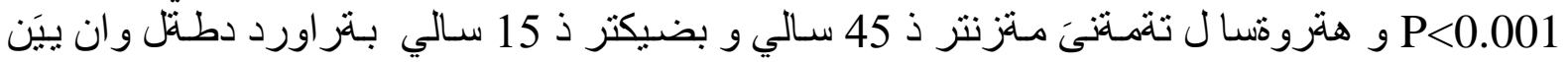

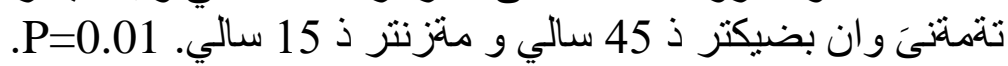

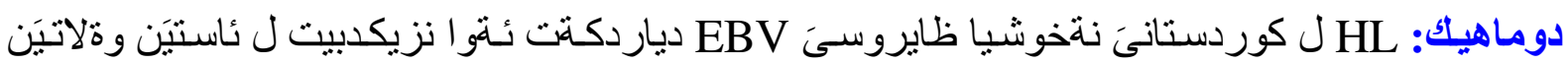

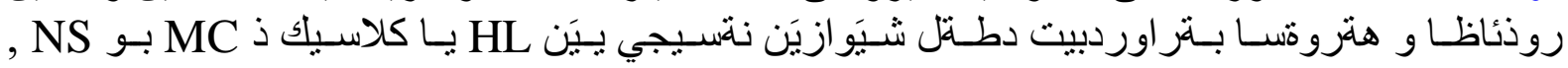

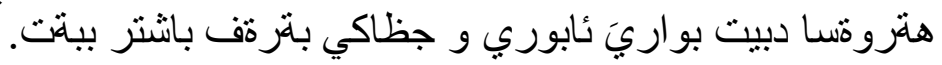




\section{الخلاصة}

\section{هودجكين ليمفوما وأرتباطها مع فيروس أبستين -بار في اقليم كردستان، العرلق}

الخلفية: تم ربط فيروس إبشتاين بار (EBV) بمسببات العديد من الأورام الخبيثة، بما في ذلك ليمفوما

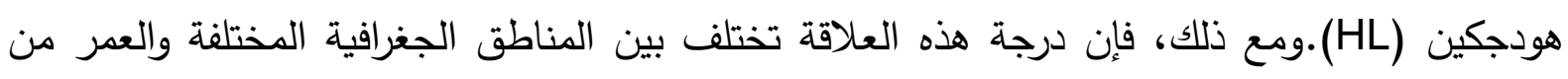
التعرض لـ EBV، وبما أن أي دراسة لم تتناول مثل هذه العلاقة في كردستان، بالتالي بدأت هذه الدراسة.

المواد والطرق: تم دراسة مجموع 92 مريض تم تثخيصهم لـ HL على مدى 10 سنوات. كان هؤلاء

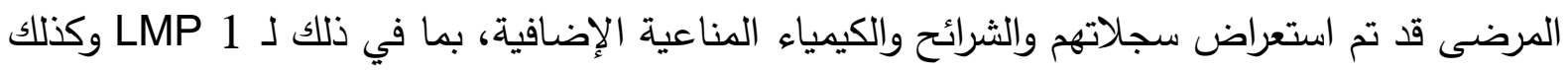
التهجين في تأدية EBER.

النتائج: كان متوسط عمر المري (17.3 ـ29.4) سنة وكانت نسبة الذكور إلى الإناث 1.7: 1. 1. وشملت 3.2٪ من النوع النسيجي الموسوم العقدة الليمفاوية السائدة ليمفوما هودجكين (NLPHL)

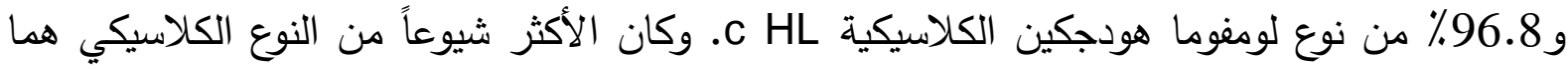

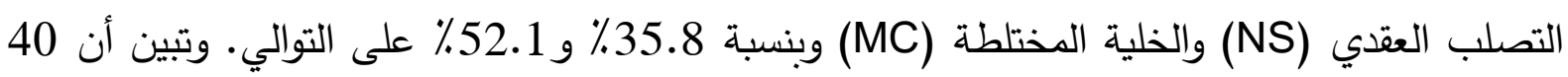

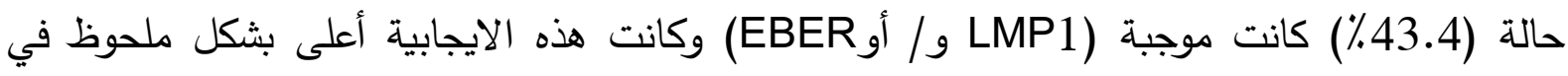

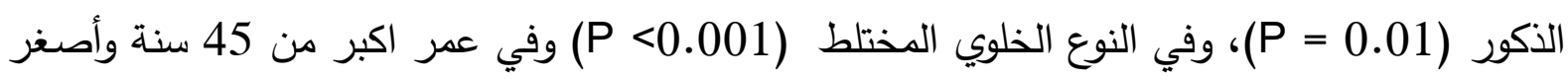

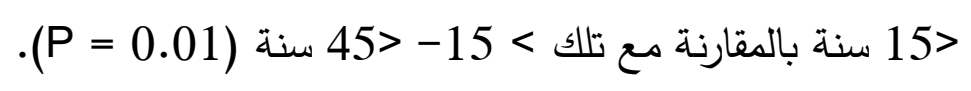

الخلاصة: تبين أن ليمفوما هودجكين في كردستان تتصاحب مع تواتر عدوى فيروس EBV ويقترب

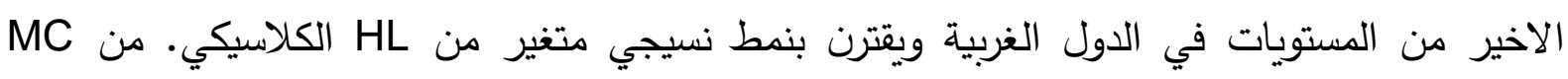
إلى NS، ومن المرجح أن يعكس هذا تحسن الوضع الاجتماعي الاقتصادي لسكان المنطقة. 